\title{
Carbonylation of diamino-ligated methylpalladium(II) methoxide complexes
}

\author{
Gerardus M. Kapteijn, Michel J. Verhoef, M.A. Frederik H. van den Broek, David M. Grove, \\ Gerard van Koten * \\ Department of Metal-Mediated Synthesis, Debye Institute, Utrecht University, Padualaan 8, 3584 CH Utrecht, The Netherlands
}

Received 20 April 1995

\begin{abstract}
The methylpalladium(II) methoxide complexes $[\mathrm{Pd}(\mathrm{Me})(\mathrm{OMe})(\mathrm{N} \sim \mathrm{N})](\mathrm{N} \sim \mathrm{N}=$ tmeda or bpy) have been synthesized by alkoxidemethanol exchange of $\left[\mathrm{Pd}(\mathrm{Me})\left(\mathrm{OCH}\left(\mathrm{CF}_{3}\right)_{2}\right)(\mathrm{N} \sim \mathrm{N})\right]$ in $\mathrm{MeOH}$. The bpy complex undergoes insertion of $\mathrm{CO}$ to give either a methyl(methoxycarbonyl) complex $\left[\mathrm{Pd}(\mathrm{Me})\left(\mathrm{CO}_{2} \mathrm{Me}\right)(\mathrm{bpy})\right]\left(\right.$ at $\left.-60^{\circ} \mathrm{C}\right)$ or an acyl(methoxycarbonyl) complex $\left[\mathrm{Pd}(\mathrm{COMe})\left(\mathrm{CO}_{2} \mathrm{Me}\right)(\mathrm{bpy})\right]$ (at $-25^{\circ} \mathrm{C}$ ). Both carbonylated species were isolated and characterized at low temperature.
\end{abstract}

Keywords: Palladium; Methoxycarbonyl complexes; Acyl; Carbonylation; Methoxide; Perfluoroalkoxide

The insertion of $\mathrm{CO}$ into a $\mathrm{Pd}-\mathrm{OMe}$ bond is one of the fundamental steps in various palladium-catalyzed organic reactions such as (i) the copolymcrization of $\mathrm{CO}$ and alkenes [1] and (ii) the methoxycarbonylation of propyne to give methyl methacrylate [2]. Surprisingly, however, only a limited number of palladium methoxide complexes have been detected in solution, and the only isolated complexes, trans-[Pd(R)(OMe $\left.\left(\mathrm{PPh}_{3}\right)_{2}\right]$, also contain electronegative $R$ groups such as $\mathrm{C}_{6} \mathrm{~F}_{5}$ and $\mathrm{CCl}=\mathrm{CCl}_{2}$ [3]. However, Tóth reported that from a solution of $\left[\mathrm{Pd}(\mathrm{Me})\left(\mathrm{O}^{t} \mathrm{Bu}\right)\{(S, S)\right.$-bdpp $\left.\}\right]((S, S)$-bdpp $=(2 S, 4 S)$-2,4-bis (diphenylphosphino)pentane) in dry $\mathrm{MeOH}$ it was possible to isolate $[\mathrm{Pd}(\mathrm{Me})(\mathrm{OMe})\{(S, S)$ bdpp\}] in $95 \%$ purity [4]. When the latter complex was treated with $\mathrm{CO}$ the methoxycarbonyl complex $\left[\mathrm{Pd}(\mathrm{Me})\left(\mathrm{CO}_{2} \mathrm{Me}\right)\{(S, S)\right.$-bdpp $\left.\}\right]$ was generated, and, furthermore, in situ-generated $\left[\mathrm{Pd}(\mathrm{OMe})_{2}(\mathrm{bpy})\right]$ was found to undergo stepwise insertion of $\mathrm{CO}$ to give the thermally stable $\left[\mathrm{Pd}\left(\mathrm{CO}_{2} \mathrm{Me}\right)_{2}(\right.$ bpy $\left.)\right]$ [5]. Recently we studied the first examples of thermally stable palladium(II) alkoxide complexes containing bidentate $\mathrm{N}$-donor ligands [6,7], but these studies failed to provide routes to palladium methoxide complexes. We report here the in situ generation of new palladium methoxides of the type $[\mathrm{Pd}(\mathrm{Me})(\mathrm{OMe})(\mathrm{N} \sim \mathrm{N})](\mathrm{N} \sim \mathrm{N}=$ tmeda or

\footnotetext{
${ }^{*}$ Corresponding author.
}

bpy) and describe the carbonylation reactions of these new species.

The ${ }^{1}$ II NMR spectra of $[\mathrm{Pd}(\mathrm{Me})(\mathrm{OR})(\mathrm{tmeda})](\mathrm{R}=$ $\left.\mathrm{CH}\left(\mathrm{CF}_{3}\right)_{2}, \mathbf{1 a} ; \mathrm{C}_{6} \mathrm{H}_{5}, \mathbf{1 b}\right)$ or $[\mathrm{Pd}(\mathrm{Me})(\mathrm{OR})(\mathrm{bpy})](\mathrm{R}=$ $\left.\mathrm{CH}\left(\mathrm{CF}_{3}\right)_{2}, 2 \mathbf{a} ; \mathrm{C}_{6} \mathrm{H}_{5}, 2 \mathbf{b}\right)$ [7] in $\mathrm{CD}_{3} \mathrm{OD}$ reveal the equilibrium shown in Scheme 1. Dissolution of $\mathbf{1 a}$ or $\mathbf{1 b}$ (ca. $15.0 \mathrm{mg})$ in $\mathrm{CD}_{3} \mathrm{OD}(0.50 \mathrm{ml})$ leads to the appearance of new PdMe and tmeda resonances together with the formation of free $\left(\mathrm{CF}_{3}\right)_{2} \mathrm{CHOH}$ or $\mathrm{C}_{6} \mathrm{H}_{5} \mathrm{OH}$, respectively. Similarly, a new set of bpy resonances and a new PdMe signal appear when $\mathbf{2 a}$ or $\mathbf{2 b}$ is dissolved in $\mathrm{CD}_{3} \mathrm{OD}$. These results are consistent with the in situ formation of new palladium methoxide complexes formulated, as shown in Scheme 1 , as $\left[\mathrm{Pd}(\mathrm{Me})\left(\mathrm{OCD}_{3}\right)\right.$ $(\mathrm{N} \sim \mathrm{N})]\left(\mathrm{N} \sim \mathrm{N}=\right.$ tmeda, $3-\mathrm{d}_{3} ;$ bpy, $\left.4-\mathrm{d}_{3}\right)[8]$.

The stability of the latter complexes under these conditions could be due to the formation of adducts of the type $\left[\mathrm{Pd}(\mathrm{Me})\left(\mathrm{OCD}_{3}\right)(\mathrm{N} \sim \mathrm{N})\right] \cdot \mathrm{HOCD}_{3}$ involving $\mathrm{O} \cdots \mathrm{H}-\mathrm{O}$ interactions (several alcohol adducts have been reported in palladium alkoxide chemistry [7,9]). However, the stability of $\mathbf{3}$ and $\mathbf{4}$ could also arise from the fact that exchange of coordinated methoxide and methanol is much faster than $\beta$-hydrogen elimination from the $\mathrm{Pd}-\mathrm{OMe}$ unit [5]. The equilibrium depicted in Scheme 1 lies almost completely over to the side of the palladium alkoxide or aryloxide complex, and so in order to achieve a significant concentration of complexes 3- $\mathrm{d}_{3}$ or $4-\mathrm{d}_{3}$ a large excess of $\mathrm{CD}_{3} \mathrm{OD}$ is needed. 


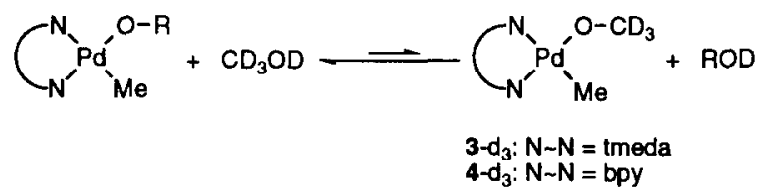

Scheme 1. Formation of palladium methoxide complexes via alkoxide/aryloxide-methanol exchange.

We also explored the possibility of trapping these in situ generated methoxide complexes with $\mathrm{CO}$ and of isolating the carbonylated species. When $\mathrm{CO}$ was bubbled through a solution of $\left[\mathrm{Pd}(\mathrm{Me})\left(\mathrm{OCH}\left(\mathrm{CF}_{3}\right)_{2}\right)(\mathrm{bpy})\right]$ (2a; $0.38 \mathrm{~g}, 1.16 \mathrm{mmol}$ ) in a minimum of $\mathrm{MeOH}$ (ca. 15 $\mathrm{ml})$ at $-60^{\circ} \mathrm{C}$ the methyl(methoxycarbonyl) complex $\left[\mathrm{Pd}(\mathrm{Me})\left(\mathrm{CO}_{2} \mathrm{Me}\right)(\right.$ bpy $\left.)\right] 5$ separated out, and was isolated at low temperatures as a yellow solid in $78 \%$ yield (see Scheme 2) [8]. Recently, Tóth reported the in situ generation of the related phosphine ligated methoxycarbonyl complex [Pd(Me) $\left(\mathrm{CO}_{2} \mathrm{Me}\right)\{(S, S)$-bdpp $\left.\}\right]$ [4]. In the ${ }^{13} \mathrm{C}$ NMR spectrum of $5\left(\mathrm{CD}_{2} \mathrm{Cl}_{2}, 243 \mathrm{~K}\right)$ the carbonyl carbon resonance is at $196.5 \mathrm{ppm}$, a value similar to that of $201.9 \mathrm{ppm}$ found for the corresponding carbon atom in $\left[\mathrm{Pd}(\mathrm{Me})\left(\mathrm{CO}_{2} \mathrm{CH}\left(\mathrm{CF}_{3}\right)_{2}\right)(\mathrm{dppe})\right]$ $\left(\mathrm{CD}_{2} \mathrm{Cl}_{2}, 213 \mathrm{~K}\right)$ [10]. There was no evidence for insertion of $\mathrm{CO}$ into the $\mathrm{Pd}-\mathrm{OCH}\left(\mathrm{CF}_{3}\right)_{2}$ bond; i.e. the formation of 5 indicates that insertion into the $\mathrm{Pd}-\mathrm{OMe}$ bond is kinetically preferred.

When $\mathrm{CO}$ was bubbled through a solution of $\mathbf{2 a}$ in $\mathrm{MeOH}$ at $-25^{\circ} \mathrm{C}$, in a procedure similar to that used for obtaining 5 at $-60^{\circ} \mathrm{C}$, an acyl(methoxycarbonyl) complex $\left[\mathrm{Pd}(\mathrm{COMe})\left(\mathrm{CO}_{2} \mathrm{Me}\right)(\mathrm{bpy})\right] 6$ was formed, and was isolated as an orange solid in $43 \%$ yield (see Scheme 2) [8]. The ${ }^{13} \mathrm{C}$ NMR spcetrum of $6\left(\mathrm{CD}_{2} \mathrm{Cl}_{2}, 243 \mathrm{~K}\right)$ shows the carbonyl carbon atoms at 192.3 and 246.8 $\mathrm{ppm}$. The presence of the latter resonance along with a signal at $42.22 \mathrm{ppm}$ points to the presence of an acylpalladium unit; such units have expected $\delta\left({ }^{13} \mathrm{C}\right)$ values of ca. $250-210 \mathrm{ppm}\left(\mathrm{COCH}_{3}\right)$ and ca. $45-30 \mathrm{ppm}$ $\left(\mathrm{COCH}_{3}\right)$ [11]. Furthermore, the $\delta\left({ }^{13} \mathrm{C}\right)$ value of 192.3 ppm for the $\mathrm{CO}_{2} \mathrm{CH}_{3}$ unit in 6 is similar to that of $196.5 \mathrm{ppm}$ found for this unit in 5. Bubbling CO through a solution of 5 in $\mathrm{MeOH}$ at $-25^{\circ} \mathrm{C}$ also to generated complex 6 and after 15 min the conversion of 5 into 6 was ca. $75 \%$ complete.

Carbonylation of the methylpalladium(II) methoxides shows that insertion of CO can take place cither into the $\mathrm{Pd}-\mathrm{OMe}$ bond or into the $\mathrm{Pd}-\mathrm{Me}$ bond (depending upon the temperature used) to give rare examples of isolable methylpalladium(II) or acylpalladium(II) methoxycarbonyl species, which can be observed as intermediates in methoxycarbonylation reactions. The relevance of these model complexes to catalytic processes is the subject of further study.

\section{Acknowledgements}

We thank Shell Research B.V. (G.M.K.) for financial support. We also thank Prof. Dr. A.J. Canty for critical comments.

\section{References and notes}

[1] E. Drent, J.A.M. van Broekhoven, M.J. Doyle, J. Organomet. Chem., 417 (1990) 235.

[2] E. Drent, P. Arnoldy, P.H.M. Budzelaar, I. Organomet. Chem., 455 (1993) 247.

[3] T. Yoshida, T. Okano, S. Otsuka, J. Chem. Soc., Dalton Trans., (1976) 993.

[4] I. Tóth, C.J. Elsevier, J. Chem. Soc., Chem. Comm., (1993) 529; I. Tóth, C.J. Elsevier, J. Am. Chem. Soc., 115 (1993) 10388.

[5] G.D. Smith, B.E. Hanson, J.S. Merola, F.J. Waller, Organometallics, 12 (1993) 568.

[6] P.L. Alsters, P.J. Baesjou, M.D. Janssen, H. Kooijman, A. Sicherer-Roetman, A.L. Spek, G. van Koten, Organometallics, 11 (1992) 4124; G.M. Kapteijn, D.M. Grove, W.J.J. Smeets, A.L. Spek, G. van Koten, Inorg. Chim. Acta, 207 (1993) 131.

[7] For synthesis and properties of $[\mathrm{Pd}(\mathrm{Me})(\mathrm{OR})(\mathrm{N}-\mathrm{N})](\mathrm{R}=$ $\mathrm{CH}\left(\mathrm{CF}_{3}\right)_{2}, \mathrm{C}_{6} \mathrm{H}_{5} ; \mathrm{N}-\mathrm{N}=$ tmeda, bpy), see: G.M. Kapteijn, A. Dervisi, D.M. Grove, H. Kooijman, M.T. Lakin, A.L. Spek, G. van Koten, J. Am. Chem. Soc., (1995) submitted.

[8] Selected spectroscopic data: NMR data recorded at $300.13 \mathrm{MHz}$ $\left({ }^{1} \mathrm{H}\right)$ or $75.04 \mathrm{MHz}\left({ }^{13} \mathrm{C}\right)$ and given as $\delta$ relative to $\mathrm{SiMe}_{4}$. Methoxide complexes: NMR data for $3-\mathrm{d}_{3}:{ }^{1} \mathrm{H}$ NMR $\left(\mathrm{CD}_{3} \mathrm{OD}\right)$ : $\delta 2.64-2.48\left(\mathrm{~m}, 4 \mathrm{H}, \mathrm{CH}_{2}\right), 2.54\left(\mathrm{~s}, 6 \mathrm{H}, \mathrm{NMe}_{2}\right), 2.50(\mathrm{~s}, 6 \mathrm{H}$,

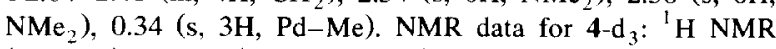
$\left(\mathrm{CD}_{3} \mathrm{OD}\right): \delta 8.72$ (broad, $\left.1 \mathrm{H}, \mathrm{H}_{6}\right), 8.65\left(\mathrm{~d}, 1 \mathrm{H}, \mathrm{H}_{6^{\prime}}\right), 8.37(\mathrm{~d}$,

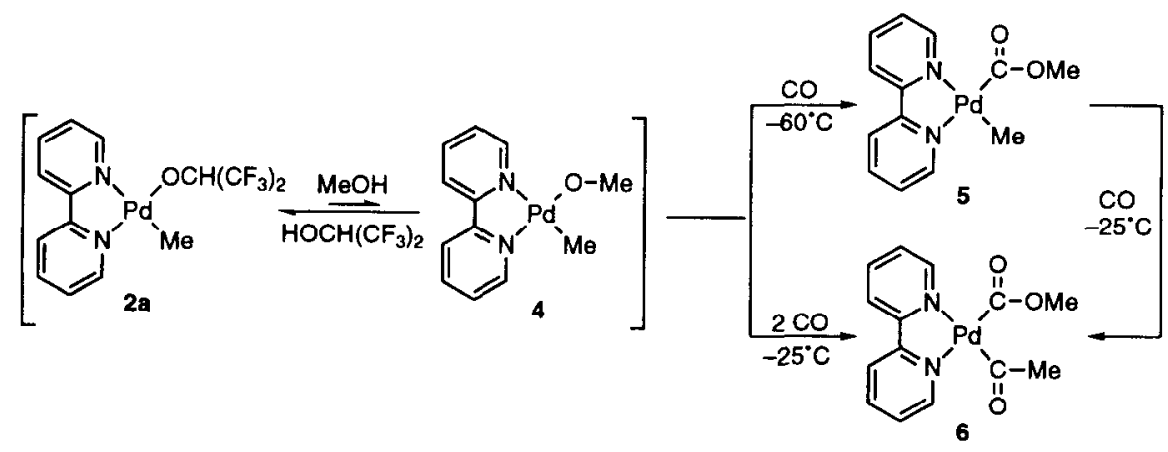

Scheme 2. Carbonylation of $\mathrm{N}$-ligated methylpalladium(II) methoxide complexes. 
$\left.2 \mathrm{H}, \mathrm{H}_{3}, \mathrm{H}_{3^{\prime}}\right), 8.12\left(\mathrm{t}, 2 \mathrm{H}, \mathrm{H}_{4}, \mathrm{H}_{4^{\prime}}\right), 7.69\left(\mathrm{t}, 1 \mathrm{H}, \mathrm{H}_{5}\right), 7.59(\mathrm{t}$, $\left.1 \mathrm{H}, \mathrm{H}_{5}\right), 0.86(\mathrm{~s}, 3 \mathrm{H}, \mathrm{Pd}-\mathrm{Me})$. Owing to the fact that $\mathrm{CD}_{3} \mathrm{OD}$ was used there is no ${ }^{1} \mathrm{H}$ NMR signal for the palladium methoxide group in $3-d_{3}$ and $4-d_{3}$.

Carbonylated complexes: Data for 5: ${ }^{1} \mathrm{H}$ NMR $\left(\mathrm{CD}_{2} \mathrm{Cl}_{2}, 243\right.$ $\mathrm{K}): \delta 8.55(\mathrm{~d}, 1 \mathrm{H}, \mathrm{H}(6)), 8.46(\mathrm{~d}, 1 \mathrm{H}, \mathrm{H}(6)), 8.16(\mathrm{~d}, 1 \mathrm{H}, \mathrm{H}(3))$, $8.13(\mathrm{~d}, 1 \mathrm{H}, \mathrm{H}(3)), 8.01(\mathrm{t}, 1 \mathrm{H}, \mathrm{H}(4)), 7.96(\mathrm{t}, 1 \mathrm{H}, \mathrm{H}(4)), 7.49$ (t, 1H, H(5)), 7.43 (t, 1H, H(5)), 3.60 (s, 3H, OMe), $0.32(\mathrm{~s}, 3 \mathrm{H}$, $\mathrm{Pd}-\mathrm{Me}) .{ }^{13} \mathrm{C} \mathrm{NMR}\left(\mathrm{CD}_{2} \mathrm{Cl}_{2}, 243 \mathrm{~K}\right): \delta 196.54(\mathrm{CO}), 155.08$, $152.28,150.61,147.65,138.90,138.43,126.54,125.87,122.14$ 121.94 (bpy), $49.61\left(\mathrm{OCH}_{3}\right),-8.41\left(\mathrm{Pd}-\mathrm{CH}_{3}\right)$. IR( $\left.\mathrm{KBr}\right)$ for 5: $\nu(\mathrm{CO}) 1630 \mathrm{~cm}^{-1}$. Data for $6:{ }^{1} \mathrm{H}$ NMR $\left(\mathrm{CD}_{2} \mathrm{Cl}_{2}, 243 \mathrm{~K}\right): \delta$ $8.53(\mathrm{~d}, 1 \mathrm{H}, \mathrm{H}(6)), 8.23$ (d, 1H, H(6)), $8.20(\mathrm{~d}, 1 \mathrm{H}, \mathrm{H}(3)), 8.10$ (d, $1 \mathrm{H}, \mathrm{H}(3)), 8.00(\mathrm{t}, 1 \mathrm{H}, \mathrm{H}(4)), 7.98(\mathrm{t}, 1 \mathrm{H}, \mathrm{H}(4)), 7.36-7.32$ $(\mathrm{m}, 2 \mathrm{H}, \mathrm{H}(5)), 3.52\left(\mathrm{~s}, 3 \mathrm{H}, \mathrm{OC} \mathrm{H}_{3}\right), 2.40\left(\mathrm{~s}, 3 \mathrm{H}, \mathrm{COCH}_{3}\right){ }^{1.3} \mathrm{C}$ NMR ( $\left.\mathrm{CD}_{2} \mathrm{Cl}_{2}, 243 \mathrm{~K}\right): \delta 246.80(\mathrm{COMe}), 192.31\left(\mathrm{CO}_{2} \mathrm{Me}\right)$, $153.70,152.89,150.50,150.14,139.29,139.21,126.17,126.01$, 122.40, 122.16 (bpy), $48.71\left(\mathrm{OCH}_{3}\right), 42.22\left(\mathrm{Pd}-\mathrm{CH}_{3}\right) . \mathrm{IR}(\mathrm{KBr})$ for 6: $\nu(\mathrm{CO}) 1641,1620 \mathrm{~cm}^{-1}$.

[9] H.E. Bryndza, W. Tam, Chem. Rer., 88 (1988) 1163; S. Komiya, Y. Akai, T. Yamamoto, A. Yamamoto, Organometallics, 4 (1985) 1130; Y.-J. Kim, K. Osakada, A. Takenaka, A. Yamamoto, J. Am. Chem. Soc., 112 (1990) 1096.

[10] Y.-J. Kim, K. Osakada, K. Sugita, T. Yamamoto, A. Yamamoto, Organometallics, 7 (1988) 2182.

[11] Y. Becker, J.K. Stille, J. Am. Chem. Soc., 100 (1978) 838; F. Ozawa, T. Sugimoto, T. Yamamoto, A. Yamamoto, Organometallics, 3 (1984) 692. 